\title{
Is huisarts die U1-visites rijdt ouderwets of innovatief?
}

\author{
Reinout van Bentveld
}

\begin{abstract}
Een kort onderzoek op een huisartsenpost bevestigt het beeld dat huisartsen makkelijk meer hoogurgente meldingen zelf kunnen afhandelen. Dat opent de weg naar nieuwe samenwerkingsvormen tussen huisarts, ambulancedienst en meldkamer ambulancezorg.
\end{abstract}

Plat et al. concluderen elders in dit nummer dat er in $40 \%$ van de U1-indicaties sprake is van overtriage en dat bij de helft van deze patiënten beter een ander zorgpad ingezet had kunnen worden. ${ }^{1}$ Op de huisartsenpost (HAP) in kwestie was het de regiearts die de $\mathrm{U} 1$ fiatteerde en bepaalde wanneer een aanvraag werd doorgezet naar de meldkamer ambulancezorg (MKA). Er zijn echter ook posten waar de triagist alle U1-meldingen doorzet naar de ambulancedienst, posten die de U1-meldingen verdelen over huisarts en ambulance, en posten waar de huisarts alle U1-visites zelf rijdt. Al deze werkwijzen zijn conform de NHG-TriageWijzer, die adviseert in geval van een U1-indicatie direct de huisarts te verwittigen zodat deze de patiënt onmiddellijk kan beoordelen, tenzij er regionaal andere afspraken gelden. De urgentie zegt echter niets over het vervolg: huisarts, ambulance of spoedeisende hulp (SEH).

\section{U1-MELDINGEN OP HUISARTSENPOST WESTLAND}

De Huisartsenpost Westland in Naaldwijk heeft geen SEH in de directe nabijheid. Het verzorgingsgebied omvat verstedelijkt platteland met 120.000 inwoners. Er zijn 55 huisartsen met 52 normpraktijken en 30\% van de diensten wordt verkocht aan waarnemers. Op de HAP rijdt de huisarts zelf in principe alle $\mathrm{U} 1$-visites. Wanneer de huisarts een sterk vermoeden heeft van ernstige pathologie kan tegelijkertijd de ambulance ingezet worden. Op deze HAP hebben we in het eerste kwartaal van 2017 de U1-verrichtingen gemonitord. Er waren dat kwartaal in totaal 7416 contacten, waarvan 1 U0, 213 (3\%) U1, 1168 (16\%) U2, 2531 (34\%) U3, 694 (9\%) U4 en 2809 (38\%) U5. De U0-visite betrof een reanimatie op verzoek van de MKA omdat er geen ambulance beschikbaar was. Bij de 213 U1-indicaties waren 17 dubbele registraties

\section{Tabel}

Inzet U1-visites Huisartsenpost Westland, januari-maart 2017

$\begin{array}{lc}\text { Huisarts } & 116[74 \%] \\ \text { Ambulance } & 40[26 \%] \\ \text { Ggz-crisisdienst } & 1[0 \%] \\ \text { Totaal } & 157[100 \%]\end{array}$

en 39 U1-consulten op de HAP; er vonden dus bij elkaar 157 U1-ritten plaats [tabel].

Van de 116 U1-visites die de huisarts reed, kon deze er 57 (50\%) zelf afhandelen. Bij 14 (35\%) van de 40 U1-ambulanceritten was overmacht in het spel doordat de huisarts meerdere spoedgevallen tegelijk moest afhandelen. Bij de overige 26 (65\%) ritten werd de ambulance op grond van de melding direct ingezet; bij een van deze meldingen ging de huisarts ook rijden. Een keer werd direct de ggz-crisisdienst ingezet. Uit het dossieronderzoek kwamen de volgende punten naar voren. - In het journaal werden geen complicaties vermeld.

- Tweemaal werd een U1-visite gereden op verzoek van de MKA.

- Meer dan de helft van de U1-indicaties betrof pijn op de borst of benauwdheid.

- De overige U1-indicaties waren vooral insulten, verwardheid, zieke indruk, oogverwonding, buik- en rugpijn, en vlekjes bij kinderen.

- Er was geen essentieel verschil tussen de U1-indicaties waarbij de huisarts zelf reed en de U1-indicaties waarbij de ambulance direct werd ingezet.

\section{EXTRA BELASTING ZORGKETEN}

Overtriage en overschatting van de ernst van de klacht zorgen voor een extra belasting van de zorgketen., ${ }^{2,3}$ Onze observatie op een HAP bevestigt de conclusie van Plat et al. ${ }^{1}$ De huisarts kan ruim een derde van de hoogurgente patiënten in eerste instantie zelf behandelen - de helft van de patiënten die de huisarts bij onze U1-visites zag, werd niet ingestuurd. Dit aandeel zou verder omhoog kunnen, al is wel verder onderzoek nodig naar de effecten daarvan. ${ }^{1,3,4}$ Ook andere samenwerkingsvormen tussen huisarts, ambulancedienst en MKA kunnen onderzocht worden. ${ }^{5}$ Gaan we weer 'ouderwets' alle visites zelf rijden?

\section{LITERATUUR}

De literatuurlijst en auteursgegevens staan bij dit artikel op www. henw.org. 